\title{
Analisis Tingkat Kepuasan Masyarakat Melalui Pelayanan Informasi Pada Aplikasi KRL Access
}

\author{
Ratnawaty Marginingsih ${ }^{1}$, Isnurrini Hidayat Susilowati ${ }^{2}$, Wiwik Widiyanti ${ }^{3}$ \\ ${ }^{1}$ Universitas Bina Sarana Informatika, ratnawaty.rmg@bsi.ac.id \\ ${ }^{2}$ Universitas Bina Sarana Informatika, isnurrini.ihs@bsi.ac.id \\ ${ }^{3}$ Universitas Bina Sarana Informatika,wiwik.www@bsi.ac.id
}

\begin{abstract}
ABSTRAK
Transportasi merupakan sarana yang sangat penting dan strategis dalam memperlancar roda perekonomian. Seiring dengan meningkatnya kebutuhan masyarakat perkotaan akan transportasi umum, kereta api menjadi salah satu pilihan alternatif tranportasi yang semakin diminati oleh masyarakat dengan banyak keunggulan seperti rendah polusi, bebas macet, bersifat massal, biaya lebih murah, dan juga waktu relatif lebih cepat. Penelitian ini bertujuan untuk mengetahui tingkat kepuasan masyarakat melalui pelayanan informasi pada aplikassi KRL Access. Sebanyak 250 responden dijadikan sampel penelitian menggunakan convenience sampling method. Bentuk penelitian yang digunakan adalah jenis penelitian deskriptif dengan pendekatan kuantitatif. Data diolah dengan dengan menggunakan analisis regeresi linier berganda. Hasil penelitian diperoleh tingkat kepuasan masyarakat melalui pelayanan informasi pada aplikassi KRL Access secara parsial dan simultan dengan menggunakan variabel reliability, responsiveness, assurance, empathy dan tangible memperoleh hasil yang positif dan signifikan. Hal ini menujukkan bahwa pelayanan yang baik menjadi salah satu kunci keberhasilan sebuah organisasi karena akan berdampak langsung pada citra perusahaan.
\end{abstract}

Kata Kunci : Kepuasan, Pelayanan Informasi, KRL Access

\begin{abstract}
Transportation is a very important and strategic means of smoothing the wheels of the economy. Along with the increasing needs of urban communities for transportation in general, the railroad has become one of the alternative transportation options that are increasingly in demand by people with many advantages such as low pollution, free of traffic, mass, cheaper cost, and also relatively faster time. This study aims to determine the level of community satisfaction through information services on the KRL Access application. A total of 250 respondents were sampled as research using the convenience sampling method. The form of research used is descriptive research with a quantitative approach. The data is processed using multiple linear regression analysis. The results obtained by the level of community satisfaction through information services on KRL Access applications partially and simultaneously by using the variables of reliability, responsiveness, assurance, empathy and tangible obtain positive and significant results. This shows that good service is one of the keys to an organization's success because it will have a direct impact on the company's image.
\end{abstract}

Keywords: Satisfaction, Information Services, KRL Access

Naskah diterima: 26-08-2020, direvisi: 19-06-2020, diterbitkan: 01-09-2020

ISSN: 2355-0295, e-ISSN: 2549-8932 


\section{PENDAHULUAN}

Transportasi merupakan sarana yang sangat penting dan strategis dalam memperlancar roda perekonomian. Hampir seluruh aktivitas masyarakat menggunakan transportasi yang bisa dipilih sesuai dengan kebutuhan masingmasing. Masyarakat di Jakarta Bogor Depok Bekasi Tangerang Banten dan Cikarang lebih menyukai Kereta Listrik (KRL) sebagai alat transportasi yang digunakan sehari-hari. Selain harga yang cukup murah, waktu yang ditempuh jauh lebih singkat dari transportasi lain menjadi alasan masyarakat memilih moda transportasi KRL.

KRL sendiri dikelola oleh PT Kereta Commuter Indonesia (KCI) yang memodernisasi kereta pada tahun 2011. Dampak dari modernisasi ini membuat masyarakat semakin nyaman menggunakan moda trasportasi ini. Hal ini dapat dilihat dari jumlah pengguna KRL selama 2019, rata-rata jumlah pengguna KRL per hari mencapai 979.853 pengguna pada hari kerja dengan 80 stasiun di seluruh Jabodetabek, Banten dan Cikarang dengan jangkauan rute mencapai 418,5 km ("Sekilas PT Kereta Commuter Indonesia," n.d.).

Tren penggunaan kereta rel listrik (KRL) atau commuter line semakin diminati oleh masyarakat saat ini. Data jumlah pengguna KRL Commuterline Jabodetabek dapat dilihat pada gambar berikut ini:

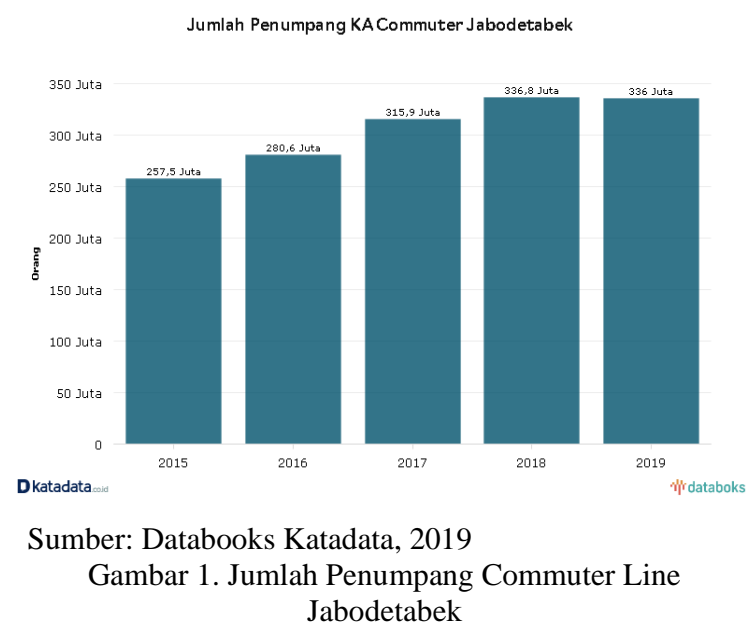

Berdasarkan data PT Kereta Commuter Indonesia (KCI) jumlah penumpang KRL sepanjang 2017 mencapai 315,9 juta penumpang naik $12,55 \%$ dari sebelumnya. Pada tahun 2018 mencapai 336,8 juta penumpang. Jumlah tersebut sekitar 868 ribu/hari. Sedangkan berdasrkan lintasannya, KRL terbanyak melayani penumpang di lintasan Depok-Bogor, yakni mencapai $69,95 \%$ dari total penumpang pada tahun lalu. Kemudian diikuti lintasan Bekasi-Cikarang sebesar 13,48\%, Serpong-Rangkasbitung $11,87 \%$ dan Tangerang $4,72 \%$ dari total penumpang KRL. ("Sekilas PT Kereta Commuter Indonesia," n.d.).

Semakin banyaknya masyarakat yang menggunakan KRL sudah semestinya diimbangi dengan pelayanan yang lebih baik. Infrastruktur rel kereta yang masih terbatas, seringkali berdampak pada kedatangan kereta yang tidak sesuai jadwal. Masyarakat yang akan menggunakan kereta seringkali harus menunggu lama atau bahkan terburu-buru mengejar kereta (Majid, 2015)

Ketidaknyamanan masyarakat atas jadwal KRL yang tidak menentu membuat pengguna KRL membutuhkan informasi kedatangan dan keberangkatan KRL secara real time. Informasi tersebut diharapkan dapat membuat para pengguna KRL bisa mengestimasi perjalanan dari rumah ke stasiun sehingga tidak perlu menunggu lama di stasiun keberangkatan.

Oleh karena itu, PT KCJ (Kereta Commuter Jobodetabek) memberikan solusi dengan mengembangkan inovasi dalam bentuk sebuah aplikasi yang bernama KRL Access. Aplikasi ini merupakan aplikasi mobile yang bertujuan memudahkan para pengguna KRL Jabodetabek. Dengan aplikasi ini maka pengguna KRL dapat dengan mudah mengetahui posisi dari KRL selain itu juga pengguna KRL akan mendapatkan berita terbaru dari sosial media milik PT KCJ (Kereta Commuter Jobodetabek). 
Pengguna dari aplikasi KRL Access tentunya memiliki beberapa persoalan ketika menggunakan aplikasi tersebut. Terlihat dari Google Play Store bahwa sejak dirilis 3 Febrauri 2014 aplikasi KRL Access hingga saat ini memiliki total jumlah unduhan pengguna sebanyak 1.000 .000 dengan ratarata rating 3,8 dari 5 bintang. Ini disebabkan oleh banyak pengguna yang memberikan ulasan negatif untuk aplikasi KRL Access. Berdasarkan ulasan yang diperoleh dari Google Play Store, banyak pengguna yang mengeluhkan tidak dapat memilih stasiun yang diinginkan, sering terjadi error sehingga pengguna merasa tidak nyaman dan terdapat fungsi yang tidak dapat digunakan (Pertiwi, Aknuranda, \& Wijoyo, 2019)

Penelitian ini pada prinsipnya bertujuan untuk menguji tingkat kepuasan pelanggan dengan metode servqual terahadap pelayanan informasi pada aplikasi kereta rel listrik (KRL) Access khususnya untuk wilayah Jabodetabek dan untuk mengetahui faktor apa saja yang harus diprioritaskan pada pelayanan informasi dengan aplikasi kereta rel listrik (KRL) Access agar dapat memenuhi harapan masyarakat.

\section{KAJIAN LITERATUR \\ Aplikasi KRL Acces}

Mobilitas masyarakat urban yang menggunakan moda transportasi KRL begitu tinggi sehingga memerlukan informasi mengenai jadwal kereta yang akan digunakan. Oleh karena itu, PT KCI berinovasi dengan mengeluarkan aplikasi KRL Access dengan fitur yang semakin memudahkan pengguna jasa kereta Commuter Line. Fitur tersebut diantaranya dapat mengetahui posisi kereta dan jadwal keberangkatan, selain itu aplikasi ini menyatukan seluruh akses informasi dari media sosial KCI ke dalam satu platform. Melalui KRL Access, pengguna juga bisa mendaftar untuk mendapatkan notifikasi langsung ke ponselnya saat ada informasi terkini seputar kondiri lintas KRL. Tidak hanya itu, aplikasi ini juga dilengkapi dengan pengiriman email komplain sebagai respon dari pihak KCI agar bisa menjadi lebih baik lagi (KRL Commuter Indonesia, 2020)

\section{Kualitas Layanan}

Pelayanan yang baik akan dapat menciptakan loyalitas pelanggan yang semakin melekat erat dan pelanggan tidak berpaling pada perusahaan lain. Kualitas layanan menjadi penting agar pengguna merasa nyaman menggunakan aplikasi tersebut. Pengguna dapat merasakan kualitas layanan baik atau buruk melalui perbandingkan persepsi para pengguna atas pelayanan yang secara nyata mereka terima atau peroleh dengan pelayanan yang sesungguhnya mereka harapkan atau inginkan terhadap atribut-atribut pelayanan suatu perusahaan (Harjati \& Venesia, 2015)

Kualitas layanan dapat dikatakan baik jika antara persepsi yang diharapkan sama dengan realita yang dirasakan oleh pengguna. Berlaku juga untuk sebaliknya. Adapun dimensi kualitas layanan ada lima yaitu: Kehandalan (Reliability), Daya tanggap (Responsiveness), Jaminan (Assurances), Empati (Empathy) dan Bukti Fisik (Tangibel) (Lovelock, Wirtz, \& Mussry, 2013).

Kelima dimensi kualitas layanan tersebut dapat mempengaruhi kepuasan pengguna dalam hal ini adalah masyarakat pengguna aplikasi KRL Access.

\section{Kepuasan Masyarakat}

Kepuasan dapat diartikan sebagai perasaan senang atau kecewa seseorang terhadap realita kinerja yang dibandingkan dengan harapan yang dipersepsikan (Kotler \& Amstrong, 2013).

Jika kinerja dibawah harapan maka konsumen tidak puas, sebaliknya bila kinerja memenuhi harapan maka konsumen akan puas dan konsumen akan sangat puas jika kinerjanya melebihi harapan. Kepuasan konsumen berarti bahwa kinerja suatu barang atau jasa sekurang-kurangnya sama dengan apa yang diharapkan.

Adapun kepuasan pelanggan adalah perasaan senang atau kecewa seseorang yang muncul setelah membandingkan antara persepsi 
terhadap kinerja (hasil) suatu produk dengan harapan-harapannya (Tjiptono \& Chandra, 2016).

Kepuasan juga merupakan fungsi dari kinerja dan harapan. Jika kinerja dibawah harapan maka konsumen tidak puas, sebaliknya bila kinerja memenuhi harapan maka konsumen akan puas dan konsumen akan sangat puas jika kinerjanya melebihi harapan.

\section{Penelitian Terdahulu}

Beberapa penelitian yang telah dilakukan oleh peneliti salah satunya meneliti mengenai pengaruh kualitas pelayanan terhadap kepuasan pelanggan pada JNE cabang Bandung. Tujuan dari penelitian ini untuk mengetahui pengaruh kualitas layanan kepuasan pelanggan baik secara bersamasama ataupun sebagian pada JNE Cabang Bandung, dimana jenis penelitian yang digunakan adalah deskriptif dengan pendekatan kuantitatif. Teknik analisa yang digunakan adalah teknik analisa deskriptif dan dengan menggunakan regresi berganda. Sedangkan sampel teknik yang digunakan adalah non probability sampel yang menggunakan total sampel sebesar 78 orang. Penelitian tersebut memperoleh hasil bahwa keseluruhan elemen kualitas pelayanan secara simultan berpengeruh terhadap kepuasan pelanggan JNE cabang Bandung, namun secara parsial hanya keandalan, jaminan, dan empati yang berpengaruh secara signifikan terhadap kepuasan pelanggan JNE cabang Bandung, sedangkan empati dan daya tanggap tidak berpengaruh secara signifikan terhadap kepuasan pelanggan JNE cabang Bandung (Panjaitan \& Yuliati, 2016)

Penelitian lain mengenai kualitas pelayanan terhadap kepuasan pelanggan telah dilakukan pada sarana transportasi angkutan umum di kota Palembang yang bertujuan untuk menguji kualitas pelayanan angkutan umum (transmusi) yang disediakan melalui kinerja terhadap kepuasan masyarakat. Penelitian tersebut menggunakan teknik analisis jalur untuk menganalisis hubungan sebab akibat yang terjadi pada regresi berganda. Hasil penelitian yang didapat adalah untuk variabel kualitas pelayanan memiliki pengaruh langsung terhadap kinerja, untuk variabel kinerja berpengaruh langsung terhadap kepuasan masyarakat, untuk variabel kualitas pelayanan berpengaruh langsung yang terhadap variabel kepuasan masyarakat, sedangkan untuk variabel kualitas pelayanan melalui kinerja terhadap kepuasan masyarakat memiliki pengaruh tidak langsung, hasil pengujian persamaan substruktur menunjukan maka pengaruh langsung ditambah pengaruh tidak langsung adalah pengaruh total, sehingga diperoleh hasil dapat disimpulkan bahwa kinerja merupakan variabel (intervening atau itermediary) (Oktariansyah, Damayanti, Usman, \& Eko, 2017)

Tidak hanya pada tingkat nasional, pada tingkat internasional juga telah melakukan penelitian serupa yaitu mengenai hubungan antara kualitas layanan dan kepuasan pelanggan di hotel-hotel Vietnam. Hasil penelitian tersebut menunjukkan bahwa Keandalan, Daya Tanggap, Jaminan, dan Empati berdampak signifikan pada kepuasan pelanggan. Studi ini menyiratkan bahwa kualitas layanan memainkan peran penting sebagai pendorong tingkat kepuasan pelanggan yang lebih tinggi dalam layanan hotel. Manajer akan fokus pada Empathy, Reliability, Responsiveness dan Assurance untuk mencapai tingkat kepuasan pelanggan yang tinggi yang mengarah pada loyalitas pelanggan dan keuntungan bisnis (Nguyen, Ha, Anh, \& Matsui, 2015)

Perbedaan penelitian ini dengan penelitian sebelumnya adalah terletak pada objek penelitian dan respondennya. Dimana objek penelitian ini adalah aplikasi KRL Access, dan reposndennya adalah masyarakat yang mempunyai KRL Access.

\section{Kerangka Pemikiran}

Berdasarkan penjelasan secara teoritis maka dapat dikembangkan suatu pola hubungan yang menggambarkan pengaruh antara masing-masing variabel kerangka pemikiran 
dalam penelitian ini dapat dilihat pada gambar berikut ini :

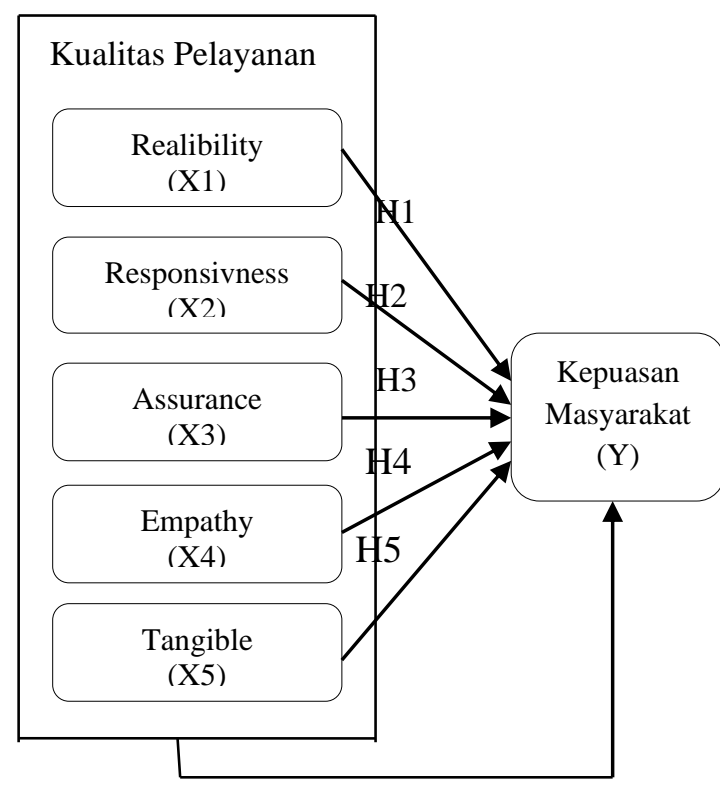

Sumber: Data diolah, 2020

Gambar 2. Kerangka Pemikiran Penelitian

Untuk hipotesis penelitian dapat dirumuskan sebagai berikut:

\begin{tabular}{|c|l|}
\hline \multicolumn{2}{|c|}{ Tabel 1 Hipotesis Penelitian } \\
\hline Hipotesis & \multicolumn{1}{|c|}{ Penjelasan } \\
\hline $\mathrm{H} 1$ & $\begin{array}{l}\text { Realibility berpengaruh positif } \\
\text { terhadap kepuasan masyarakat }\end{array}$ \\
\hline $\mathrm{H} 2$ & $\begin{array}{l}\text { Responsivness berpengaruh } \\
\text { positif terhadap kepuasan } \\
\text { masyarakat }\end{array}$ \\
\hline $\mathrm{H} 3$ & $\begin{array}{l}\text { Assurance berpengaruh positif } \\
\text { terhadap kepuasan masyarakat }\end{array}$ \\
\hline $\mathrm{H} 4$ & $\begin{array}{l}\text { Empathy berpengaruh positif } \\
\text { terhadap kepuasan masyarakat }\end{array}$ \\
\hline $\mathrm{H} 5$ & $\begin{array}{l}\text { Tangible berpengaruh positif } \\
\text { terhadap kepuasan masyarakat }\end{array}$ \\
\hline
\end{tabular}

\section{METODE PENELITIAN}

Dalam penelitian ini, jenis penelitian yang digunakan adalah jenis penelitian deskriptif dengan pendekatan kuantitatif. Lokasi penelitian dilakukan di setiap stasiun pemberhentian yang ada di wilayah Jabodetabek. Pengumpulan data diperoleh dengan membagikan kuesioner kepada pelanggan yang berada di stasiun dan melakukan survey secara online. Sebanyak 250 responden dijadikan sebagai sampel penelitian. Teknik pengambilan sampel menggunakan convenience sampling method dimana pengambilan sempel dengan mengumpulkan informasi dari anggotaanggota populasi yang mudah diperoleh dan mampu menyediakan informasi tersebut. Dengan demikian siapa saja yang dapat memberikan informasi baik secara tidak sengaja atau kebetulan bertemu dengan peneliti, dapat digunakan sebagai sampel, bila dilihat orang yang memberikan informasiinformasi tersebut cocok sebagai sumber data (Sekaran, 2017)

Langkah awal yang dilakukan adalah menyebarkan kuesioner secara langsung dan online kepada semua kalangan antara usia dibawah 20 tahun sampai diatas 40 tahun dengan berbagai latar belakang pendidikan dan pekerjaan yang dijadikan sebagai data demografi responden. Instrumen yang digunakan melalui kuesioner berisi pernyataan tentang faktor yang mempengaruhi kepuasan penggunaan aplikasi KRL Accses meliputi kehandalan (reliability), daya tanggap (responsiveness), jaminan (assurances), empati (empathy), dan bukti fisik (tangibel).

Kuesioner yang disebar menggunakan skala likert untuk mengukur besarnya persepsi responden atas suatu pernyataan yang diajukan peneliti. Data yang dihasilkankan diuji tingkat kevalidannya dan reliabilitasnya. Validitas adalah tingkat keandalan dan kesahihan alat ukur yang digunakan.intrumen dikatakan valid berarti menunjukkan alat ukur yang dipergunakan untuk mendapatkan data itu valid atau dapat digunakan untuk mengukur apa yang seharusnya di ukur. (Sugiono, 2016)

Langkah kedua adalah memproses data penelitian dalam pengukuran yang valid dan reliabel untuk keseluruhan faktor yang digunakan sehingga kepuasan masyarakat

ISSN: 2355-0295, e-ISSN: 2549-8932

190 
terhadap kualitas layanan KRL Access dapat diukur. Teknik analisis data yang dilakukan dalam penelitian ini adalah analisis regresi berganda dengan bertujuan untuk mengetahui pengaruh secara parsial maupun simultan variabel independen terhadap variabel independen. Analisis yang digunakan adalah regresi berganda, maka sebelum menggunakan analisis tersebut terlebih dahulu dilakukan uji asumsi klasik. Adapun persamaan regresi linear berganda yang digunakan adalah sebagai berikut:

$\mathrm{Y}=\beta 0+\beta 1 \mathrm{X} 1+\beta 2 \mathrm{X} 2+\beta 3 \mathrm{X} 3+\beta 4 \mathrm{X} 4+$ $\beta 5 \mathrm{X} 5+\mathrm{e}$

Dimana :

Y : Kepuasan Masyarakat

$\beta 0 \quad$ : Konstanta

$\beta 1 \ldots \beta 5$ : Koefisien masing masing variabel independen

$\mathrm{X} 1 \quad$ : Reliability

$\mathrm{X} 2$ : Responsiveness

$\mathrm{X} 3$ : Assurance

X4 : Empathy

X5 : Tangible

e : Standar Error

\section{PEMBAHASAN}

\section{A. Deskripsi Objek Penelitian}

Data hasil penelitian diperoleh sebanyak 250 responden sebagai sampel dengan menyebarkan kuesioner secara langsung dan online yang berpartisipasi dan menjawab pertanyaan secara penuh. Kuesioner yang disebar mencakup data karakteristik responden seperti jenis kelamin, usia, pendidikan dan pekerjaan. Pada tabel 2 disajikan data karakteristik responden sebagai berikut:

Tabel 2. Data Karakteristik Responden

\begin{tabular}{|l|c|}
\hline Gender & $\mathbf{( \% )}$ \\
\hline Wanita & 58,3 \\
\hline Pria & 41,7 \\
\hline & \\
\hline Usia & $\mathbf{( \% )}$ \\
\hline$<19$ & 15,5 \\
\hline $20-29$ & 26,2 \\
\hline
\end{tabular}

\begin{tabular}{|l|l|}
\hline $30-39$ & 20,2 \\
\hline $40-49$ & 21,4 \\
\hline$>50$ & 16,7 \\
\hline & \\
\hline Pendidikan Terakhir & $\mathbf{( \% )}$ \\
\hline SMU/SMK/Sederajat & 34,6 \\
\hline D3 & 9,5 \\
\hline S1 & 23,8 \\
\hline S2 & 32,1 \\
\hline S3 & 1,5 \\
\hline & \\
\hline Pekerjaan & $\mathbf{( \% )}$ \\
\hline Pelajar/Mahasiswa & 27,4 \\
\hline Wiraswasta & 4,2 \\
\hline Pegawai Negeri & 7,7 \\
\hline Karyawan Swasta & 34.5 \\
\hline Lain-lain & 26,2 \\
\hline & \\
\hline Lamanya menggunakan & $\mathbf{( \% )}$ \\
\hline \multicolumn{1}{|c|}{ KRL Acess } & \\
\hline$<1$ tahun & 41,7 \\
\hline$<2$ tahun & 29,8 \\
\hline$<3$ tahun & 13,1 \\
\hline$<4$ tahun & 3,5 \\
\hline$<5$ tahun & 11,9 \\
\hline & \\
\hline Sumber: Hanil Penelting & \\
\hline
\end{tabular}

Sumber: Hasil Penelitian, 2020

Berdasarkan tabel 2 diperoleh data bahwa responden yang paling banyak menggunakan KRL Acess adalah wanita sebanyak 58,3\% sedangkan responden berusia 20-29 mendominasi sebesar 26,2 \%. Responden berpendidikan terakhir SMU/SMK/Sederajat adalah paling banyak mengisi kuisioner sebesar 34,6\%. Adapun pekerjaan responden yang paling banyak adalah sebagai karyawan swasta. Lamanya waktu menggunakan KRL access paling banyak pada jangka waktu kurang dari satu tahun yaitu sebesar $41,7 \%$. Hal ini dapat diartikan bahwa, KRL Access banyak dikenal orang dalam satu tahun terakhir.

\section{B. Uji Validitas dan Reliabilitas}

Uji validitas dan reliabilitas variabel penelitian terhadap responden merupakan 
prosedur agar data yang diperoleh layak untuk pengujian. Uji ini digunakan untuk menguji data yang menggunakan daftar pertanyaan atau kuesioner untuk melihat pertanyaan dalam kuesioner yang diisi oleh responden tersebut layak atau belum. Hasil pengujian dapat dilihat pada tabel berikut:

Tabel 3. Uji Validitas

\begin{tabular}{|c|c|c|c|c|}
\hline Variabel & $\begin{array}{c}\text { Item } \\
\text { Pertanyaan }\end{array}$ & $\begin{array}{c}\mathbf{r} \\
\text { hitung }\end{array}$ & $\begin{array}{c}\mathbf{r} \\
\text { tabel }\end{array}$ & Ket \\
\hline \multirow[t]{7}{*}{ Reliability } & Item_1 & 0.266 & 0.124 & Valid \\
\hline & Item_2 & 0.278 & 0.124 & Valid \\
\hline & Item_3 & 0.338 & 0.124 & Valid \\
\hline & Item_4 & 0.363 & 0.124 & Valid \\
\hline & Item_5 & 0.397 & 0.124 & Valid \\
\hline & Item_6 & 0.462 & 0.124 & Valid \\
\hline & Item_7 & 0.589 & 0.124 & Valid \\
\hline \multirow[t]{5}{*}{ Responsivness } & Item_8 & 0.465 & 0.124 & Valid \\
\hline & Item_9 & 0.559 & 0.124 & Valid \\
\hline & Item_10 & 0.584 & 0.124 & Valid \\
\hline & Item_11 & 0.576 & 0.124 & Valid \\
\hline & Item_12 & 0.483 & 0.124 & Valid \\
\hline \multirow[t]{4}{*}{ Assurance } & Item_13 & 0.296 & 0.124 & Valid \\
\hline & Item_14 & 0.536 & 0.124 & Valid \\
\hline & Item_15 & 0.456 & 0.124 & Valid \\
\hline & Item_16 & 0.620 & 0.124 & Valid \\
\hline \multirow[t]{5}{*}{ Empathy } & Item_17 & 0.351 & 0.124 & Valid \\
\hline & Item_18 & 0.589 & 0.124 & Valid \\
\hline & Item_19 & 0.410 & 0.124 & Valid \\
\hline & Item_20 & 0.547 & 0.124 & Valid \\
\hline & Item_21 & 0.406 & 0.124 & Valid \\
\hline \multirow[t]{4}{*}{ Tangible } & Item_22 & 0.262 & 0.124 & Valid \\
\hline & Item_23 & 0.470 & 0.124 & Valid \\
\hline & Item_24 & 0.460 & 0.124 & Valid \\
\hline & Item_25 & 0.387 & 0.124 & Valid \\
\hline Variabel & $\begin{array}{c}\text { Item } \\
\text { Pertanyaan }\end{array}$ & $\begin{array}{c}\mathbf{r} \\
\text { hitung }\end{array}$ & $\begin{array}{c}\mathbf{r} \\
\text { tabel }\end{array}$ & Ket \\
\hline \multirow{4}{*}{$\begin{array}{c}\text { Kepuasan } \\
\text { Masyarakat }\end{array}$} & Item_1 & 0.405 & 0.124 & Valid \\
\hline & Item_2 & 0.569 & 0.124 & Valid \\
\hline & Item_3 & 0.399 & 0.124 & Valid \\
\hline & Item_4 & 0.530 & 0.124 & Valid \\
\hline
\end{tabular}

ISSN: 2355-0295, e-ISSN: 2549-8932 http://ejournal.bsi.ac.id/ejurnal/index.php/ecodemica

\begin{tabular}{|c|c|c|c|}
\hline Item_5 & 0.457 & 0.124 & Valid \\
\hline Item_6 & 0.639 & 0.124 & Valid \\
\hline
\end{tabular}

Sumber: Hasil Penelitian, 2020

Berdasarkan hasil pengolahan data pada tabel diatas, item pertanyaan pada setiap variabel yang digunakan menujukkan semuanya valid, sebab nilai $r$ hitung lebih besar dari nilai $r$ tabel ( $r$ hitung $>r$ tabel). Sedangkan untuk uji reliabilitas pada setiap variabel yang digunakan pada penelitian, dapat dilihat pada tabel berikut ini:

Tabel 4. Uji Reliabilitas

\begin{tabular}{|c|c|c|c|}
\hline Variabel & $\begin{array}{c}\text { Cronbach } \\
\text { Alpha }\end{array}$ & Standar & Ket \\
\hline Realibility & 0.755 & 0.60 & Reliabel \\
\hline Responsivness & 0.854 & 0.60 & Reliabel \\
\hline Assurance & 0.821 & 0.60 & Reliabel \\
\hline Empathy & 0.825 & 0.60 & Reliabel \\
\hline Tangible & 0.78 & 0.60 & Reliabel \\
\hline $\begin{array}{l}\text { Kepuasan } \\
\text { Masyarakat }\end{array}$ & 0.854 & 0.60 & Reliabel \\
\hline
\end{tabular}

Sumber: Hasil Penelitian, 2020

Berdasarkan hasil pengolahan data yang tersaji dalam tabel 4 , semua variabel dalam penelitian ini reliabel, hal itu dapat dilihat dari nilai cronbach alpha pada semua variabel memiliki nilai yang lebih besar dari nilai standar

\section{Uji Asumsi Klasik \\ Uji Normalitas}

Uji normalitas digunakan sebagai langkah awal untuk mengetahui dalam model regresi penelitian apakah terdapat variabel pengganggu atau residual yang memiliki distribusi normal atau tidak. Uji normalitas dapat dilakukan dengan menggunakan metode grafik Normal Probability Plot atau dengan metode One Sample Kolmogrof-Smirnov. Hasil uji normalitas data pada penelitian ini dilihat sebagai berikut: 
Tabel 5. Uji Normalitas

\begin{tabular}{|l|l|r|}
\hline \multicolumn{2}{|c|}{ One-Sample Kolmogorov-Smirnov Test } \\
\hline \multirow{2}{*}{$\mathrm{N}$} & \multicolumn{1}{|c|}{$\begin{array}{c}\text { Unstandardized } \\
\text { Residual }\end{array}$} \\
\hline $\begin{array}{l}\text { Normal } \\
\text { Parameters }\end{array}$ & Mean & 250 \\
\cline { 2 - 3 } & $\begin{array}{l}\text { Std. } \\
\text { Deviation }\end{array}$ \\
\hline $\begin{array}{l}\text { Most Extreme } \\
\text { Differences }\end{array}$ & Absolute \\
\cline { 2 - 3 } & Positive & 0.091 \\
\cline { 2 - 3 } & Negative & 0.037 \\
\hline Kolmogorov-Smirnov Z & -0.091 \\
\hline Asymp. Sig. (2-tailed) & 0.982 \\
\hline \multicolumn{2}{|l|}{ a. Test distribution is Normal. } \\
\hline \multicolumn{2}{|l|}{ b. Calculated from data. } \\
\hline \multicolumn{2}{|l}{ Sumber: Hasil Penelita } \\
\hline
\end{tabular}

Sumber: Hasil Penelitian, 2020

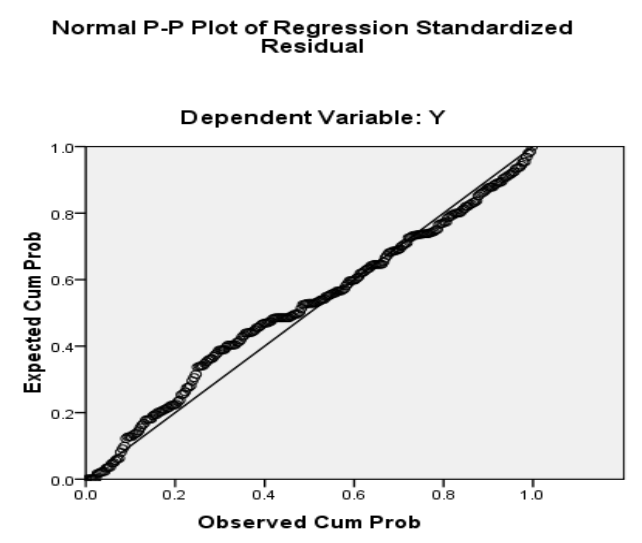

Sumber: Hasil Penelitian, 2020

Gambar 3. Diagram Plot Normalitas Data

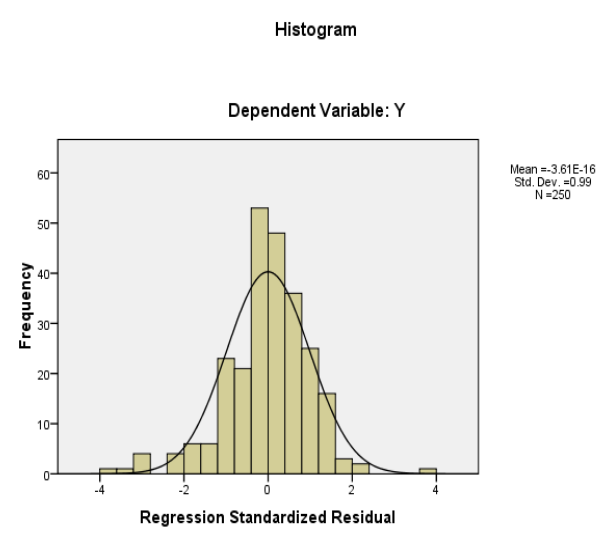

Sumber: Hasil Penelitian, 2020

Gambar 4. Grafik Histogram
Berdasarkan hasil uji normalitas pada tabel 2 dengan menggunakan uji Kolmogrov-Smirnov menujukkan hasil sebesar 0,433 yang berarti bahwa seluruh variabel memiliki nilai asymp. Sig (2-tailed) diatas 0,05. Sedangakan berdasarkan uji normalitas pada gambar 3 dan 4 dengan menggunakan grafik dapat dilihat bahwa titik-titik menyebar disekitar garis diagonal atau mengikuti arah garis diagonal. Dengan demikian dapat disimpulkan bahwa semua variabel telah terdistribusi normal dan model regresi layak digunakan.

\section{Uji Multikolinieraritas}

Uji multikolinieritas diperlukan untuk mengetahui ada tidaknya variabel independen yang memiliki kemiripan dengan variabel independen lain dalam satu model. Hasil uji multikolinieritas pada penelitian ini dilihat sebagai berikut:

Tabel 6. Uji Multikolinearitas

\begin{tabular}{|c|c|c|}
\hline Variabel & Tolerence & VIP \\
\hline $\mathrm{X} 1$ & 0.719 & 1.392 \\
\hline $\mathrm{X} 2$ & 0.756 & 1.324 \\
\hline $\mathrm{X} 3$ & 0.700 & 1.429 \\
\hline $\mathrm{X} 4$ & 0.597 & 1.674 \\
\hline $\mathrm{X} 5$ & 0.650 & 1.539 \\
\hline \multicolumn{2}{|c|}{ Sumber: Hasil Penelitian, 2020 } \\
\hline
\end{tabular}

Hasil uji melalui Variance Inflation Factor (VIP) pada hasil output SPSS tabel Coefficients, seluruh variabel menujukkan nilai tolerance $>0,1$ dan VIF $<10$, maka dapat dinyatakan model regresi linier berganda terbebas dari multikolinearitas dan dapat digunakan dalam penelitian

\section{Uji Autokorelasi}

Autokorelasi merupakan korelasi antara anggota observasi yang disusun menurut waktu atau tempat. Model regresi yang baik 
seharusnya tidak terjadi autokorelasi. Hasil uji autokorelasi pada penelitian ini dapat dilihat pada tabel berikut:

Tabel 7. Uji Autokorelasi

\begin{tabular}{|c|}
\hline Durbin-Watson \\
\hline 1.817 \\
\hline
\end{tabular}

Sumber: Hasil Penelitian, 2020

Dari hasil output SPSS didapatkan nilai Durbin-Watson untuk model regresi kepuasan masyarakat sebagai variabel dependen senilai 1,817. Hasil nilai Durbin-Watson hitung terletak diantara batas atas (du) dan batas

\begin{tabular}{|l|l|c|c|c|}
\hline \multicolumn{2}{|c|}{ Model } & \multicolumn{2}{|c|}{$\begin{array}{c}\text { Unstandardized } \\
\text { Coefficients }\end{array}$} & $\begin{array}{c}\text { Standardized } \\
\text { Coefficients }\end{array}$ \\
\cline { 3 - 5 } & \multicolumn{2}{|c|}{} & \\
\cline { 3 - 5 } & & B & $\begin{array}{c}\text { Std. } \\
\text { Error }\end{array}$ & Beta \\
\hline & (Constant) & 5.110 & 1.515 & \\
\hline & X1 & 0.278 & 0.046 & 0.291 \\
\hline & X3 & 0.283 & 0.038 & 0.357 \\
\hline & X4 & 0.296 & 0.067 & 0.219 \\
\hline & X5 & 0.487 & 0.064 & 0.406 \\
\hline & 0.237 & 0.102 & 0.119 \\
\hline
\end{tabular}

a. Dependent Variable: $Y$

bawah (4-du) atau du < dw < 4-du yaitu 1,760 $<1,817<2,175$ sehingga keputusan yang diambil adalah tidak adanya autokorelasi negatif dan positif atau dengan kata lain tidak ada autokorelasi dalam model regresi ini. Dengan demikian dapat dikatakan bahwa model terbebas dari autokorelasi.

\section{Uji Heteroskedastisitas}

Pengujian heteroskedastisitas digunakan untuk melihat apakah dalam model regresi terjadi ketidaksamaan dari pengamatan satu kepengamatan lainnya. Model regresi dalam penelitian dikatakan baik apabila terhindar atau terbebas dari heteroskedastisitas. Hasil uji heteroskedastisitas pada penelitian ini dapat dilihat pada gambar dibawah ini:

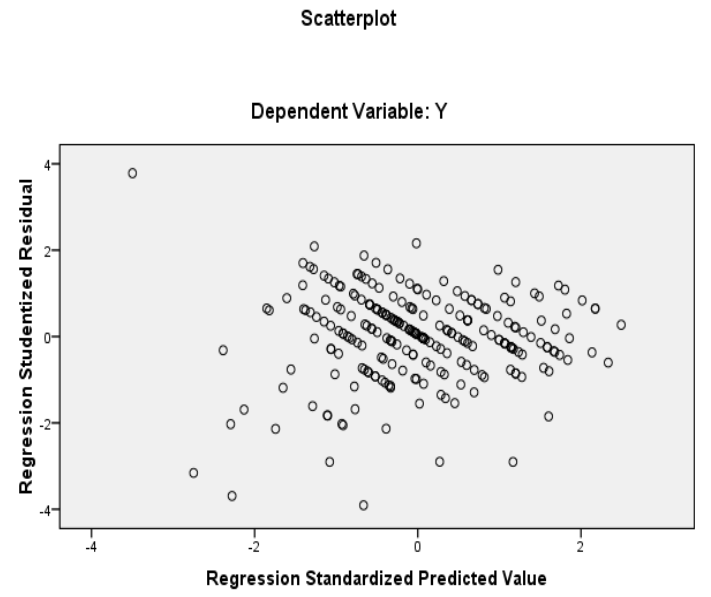

Sumber: Hasil Penelitian, 2020

\section{Gambar 3. Grafik Scatterplot}

Dari grafik scatterplot terlihat bahwa titik-titik menyebar secara acak serta tersebar baik diatas maupun dibawah angka 0 pada sumbu Y dengan demikian dapat disimpulkan bahwa model regresi ini tidak terjadi heteroskedastisitas.

\section{Analisis Regresi Berganda}

Hasil perhitungan Regresi Linier Berganda dapat dilihat pada tabel berikut:

Tabel 8. Hasil Regresi Berganda

Sumber: Hasil Penelitian, 2020

Berdasarkan hasil pada tabel 8 diperoleh persamaan regresi sebagai berikut:

$$
\begin{aligned}
& Y=5,110+0,278 \times 1+0,283 X 2+0,296 \times 3 \\
& +0,487 X 4+0,237 X 5+\varepsilon
\end{aligned}
$$

Intrepretasi dari persamaan regresi linier berganda tersebut adalah:

Nilai konstanta (a) sebesar 5.110. Hal ini menunjukkan bahwa jika variabel independen Reliability (X1), Responsivness (X2), Assurance (X3), Empathy (X4), Tangible (X5) diasumsikan dalam keadaan tetap, maka 
variabel dependen Kepuasan Masyarakat (Y) akan naik sebesar 5.110

Nilai koefisien regresi Reliability (X1), bernilai positif yaitu sebesar 0,278 yang berarti jika variabel Reliability (X1) naik sebesar 1 satuan dengan asumsi variabel independen lain nilainya tetap, maka Kepuasan Masyarakat akan naik sebesar 0,278 satuannya.

Nilai koefisien regresi Responsivness (X2), bernilai positif yaitu sebesar 0,283 yang berarti jika variabel Responsivness (X2) naik sebesar 1 satuan dengan asumsi variabel independen lain nilainya tetap, maka Kepuasan Masyarakat akan naik sebesar 0,283 satuannya.

Nilai koefisien regresi Assurance (X3) bernilai positif yaitu sebesar 0,296 yang berarti jika variabel Assurance (X3) naik sebesar 1 satuan dengan asumsi variabel independen lain nilainya tetap, maka Kepuasan nasabah akan naik sebesar 0,296 satuannya.

Nilai koefisien regresi Empathy (X4) bernilai positif yaitu sebesar 0,487 yang berarti jika variabel Empathy (X4) naik sebesar 1 satuan dengan asumsi variabel independen lain nilainya tetap, maka Kepuasan Masyarakat akan naik sebesar 0,487 satuannya.

Nilai koefisien regresi Tangible (X5) bernilai positif yaitu sebesar 0,237 yang berarti jika variabel Tangible (X5) naik sebesar 1 satuan dengan asumsi variabel independen lain nilainya tetap, maka Kepuasan Masyarakat akan naik sebesar 0,237 satuannya.

\section{E. Analisa Koefisien Determinasi $\left(\mathbf{R}^{\mathbf{2}}\right)$}

Koefisien determinasi $\left(\mathrm{R}^{2}\right)$ digunakan untuk mengukur seberapa jauh kemampuan model dalam menerangkan variasi variable dependennya. Nilai $\mathrm{R}^{2}$ yang mendekati satu berarti variable-variabel independennya memberikan hampir semua informasi yang dibutuhkan untuk memprediksi variasi variabel dependen. Hasil perhitungan koefisien determinasi dapat dilihat pada tabel berikut:
Tabel 9. Koefisien Determinasi

\begin{tabular}{|r|c|c|c|c|}
\hline \multicolumn{5}{|c|}{ Model Summary $^{\mathbf{b}}$} \\
\hline Model & $\mathrm{R}$ & $\begin{array}{c}\mathrm{R} \\
\text { Square }\end{array}$ & $\begin{array}{c}\text { Adjusted } \\
\mathrm{R} \\
\text { Square }\end{array}$ & $\begin{array}{c}\text { Std. Error of } \\
\text { the Estimate }\end{array}$ \\
\hline 1 & $0.863^{\mathrm{a}}$ & 0.782 & 0.722 & 1.91459 \\
\hline \multicolumn{3}{|l|}{} \\
\hline \multicolumn{2}{|l|}{ b. Predictors: (Constant), X5, X2, X3, X1, X4 } \\
\hline
\end{tabular}

Sumber: Hasil Penelitian, 2020

Berdasarkan hasil pada tabel 9 pengujian koefisien determinasi R Square $\left(\mathrm{R}^{2}\right)$ Kepuasan Masyarakat diperoleh nilai sebesar 0,782. Dengan kata lain hal ini menunjukkan bahwa besar presentase variasi Kepuasan Masyarakat yang bisa dijelaskan oleh variasi dari kelima variabel bebas yaitu Reliability (X1), Responsivness (X2), Assurance (X3), Empathy (X4), Tangible (X5) sebesar 78,2\%, sedangkan sisanya sebesar $21,8 \%$ dijelaskan oleh sebab-sebab lain diluar model penelitian yang digunakan.

\section{F. Hasil Uji F}

Uji $\mathrm{F}$ digunakan untuk mengetahui pengaruh variabel bebas secara bersama-sama (simultan) terhadap variabel terikat (Ghazali, 2016) Hasil perhitungan uji $\mathrm{F}$ dapat dilihat pada tabel berikut:

Tabel 10. Hasil Uji F

\begin{tabular}{|l|l|l|c|c|c|}
\hline \multicolumn{7}{|c|}{ ANOVA $^{\text {b }}$} \\
\hline \multicolumn{2}{|l|}{ Model } & $\begin{array}{l}\text { Sum of } \\
\text { Squares }\end{array}$ & df & F & Sig. \\
\hline 1 & Regression & 1243.977 & 5 & 67.872 & $.000^{\text {a }}$ \\
\cline { 2 - 6 } & Residual & 894.423 & 244 & & \\
\cline { 2 - 6 } & Total & 2138.4 & 249 & & \\
\hline \multicolumn{2}{|l|}{ a. Predictors: (Constant), X5, X2, X3, X1, X4 } \\
\hline
\end{tabular}

ISSN: 2355-0295, e-ISSN: 2549-8932 
b. Dependent Variable: Y

Sumber: Hasil Penelitian, 2020

Berdasarkan hasil output pada tabel 10 menunjukkan bahwa F-hitung (F-Statitstik) sebesar 67,872 sedangkan F-tabel dengan df 2 $(n-k-1)=244$ adalah 3,032 dengan demikian F-Hitung > F-Tabel $(67,872>3,032)$ pada tingakt signifikansi $<0,05(0,000<0,05)$ artinya semua variabel independen secara bersama-sama berpengaruh signifikan terhadap variabel dependen. Adapun besarnya pengaruh menggunakan model summmary telah dijelaskan pada tabel 9 .

\section{G. Hasil Uji t}

Pengujian ini dilakukan untuk mengetahui apakah terdapat pengaruh dari masing-masing variabel bebas terhadap variabel terikat. Uji ini dapat dilakukan dengan melihat kolom signifikansi dengan membandingkan tingkat signifikansi $5 \%(\alpha=0,05)$. Hasil uji t dapat diketahui melalui tabel berikut ini:

Tabel 11. Hasil Uji t

\begin{tabular}{|c|c|c|c|}
\hline \multicolumn{4}{|c|}{ Coefficients $^{a}$} \\
\hline \multicolumn{2}{|c|}{ Model } & $\mathrm{t}$ & Sig. \\
\hline \multirow[t]{6}{*}{1} & (Constant) & 3.374 & 0.000 \\
\hline & $\mathrm{X} 1$ & 4.907 & 00.00 \\
\hline & $\mathrm{X} 2$ & 7.503 & 0.000 \\
\hline & $\mathrm{X} 3$ & 4.421 & 0.000 \\
\hline & $\mathrm{X} 4$ & 7.575 & 0.000 \\
\hline & $\mathrm{X} 5$ & 2.317 & 0.021 \\
\hline \multicolumn{4}{|c|}{ a. Dependent Variable: $\mathrm{Y}$} \\
\hline \multicolumn{3}{|c|}{ Sumber: Hasil Penelitian, 2020} & \\
\hline
\end{tabular}

Hasil perhitungan pada tabel 11 diperoleh nilai $\mathrm{t}$ dapat dicari dengan level of signifi cance (a) $=0,05$ dan derajat tabel kebebasan $($ degree of freedom $=\mathrm{df})=\mathrm{n}-\mathrm{k}-1$, maka besarnya nilai t-tabel dapat ditentukan sebagai berikut: t-tabel adalah a ; $\mathrm{n}-\mathrm{k}=0,05 ;(250-6)$ $=1,969$. Adapun cara pengujian uji $\mathrm{t}$ untuk masing-masing variabel adalah sebagai berikut:
Hipotesis 1 menunjukan terdapat pengaruh positif dan signifikan variabel reliability (X1) terhadap kepuasan masyarakat. Pembuktian untuk hipotesis tersebut digunakan perbandingan t-hitung dengan t-tabel, dimana diperoleh nilai t-hitung lebih besar dari pada ttabel $(4.907>1,969)$. Hasil nilai p-value sebesar 0,000 $<0,05$ (alpha 5\%), maka Ha diterima dan disimpulkan secara statistik pada tingkat kepercayaan 95\% terdapat pengaruh positif reliability (X1) terhadap kepuasan nasabah.

Hipotesis 2 menunjukan terdapat pengaruh positif dan signifikan responsivness (X2) terhadap kepuasan masyarakat. Pembuktian untuk hipotesis tersebut digunakan perbandingan t-hitung dengan t-tabel, dimana diperoleh nilai t-hitung lebih besar dari pada ttabel $(7.503>1,969)$. Hasil nilai $p$-value sebesar 0,000 $<0,05$ (alpha 5\%), maka Ha diterima dan disimpulkan secara statistik pada tingkat kepercayaan 95\% terdapat pengaruh positif responsivness (X2) terhadap kepuasan masyarakat.

Hipotesis 3 menunjukan terdapat pengaruh positif dan signifikan variabel assurance (X3) terhadap kepuasan masyarakat. Pembuktian untuk hipotesis tersebut digunakan perbandingan t-hitung dengan t-tabel, dimana diperoleh nilai t-hitung lebih besar dari pada ttabel $(4,421>1,969)$. Hasil nilai $p$-value sebesar $0,000<0,05$ (alpha 5\%), maka Ha diterima dan disimpulkan secara statistik pada tingkat kepercayaan 95\% terdapat pengaruh positif assurance (X3) terhadap kepuasan masyarakat

Hipotesis 4 menunjukan terdapat pengaruh positif dan signifikan variabel empathy (X4) terhadap kepuasan masyarakat. Pembuktian untuk hipotesis tersebut digunakan perbandingan t-hitung dengan t-tabel, dimana diperoleh nilai t-hitung lebih besar dari pada ttabel $(7,575>1,969)$. Hasil nilai $p$-value sebesar 0,000 <0,05 (alpha 5\%), maka Ha diterima dan disimpulkan secara statistik pada tingkat kepercayaan 95\% terdapat pengaruh positif empathy (X4) terhadap kepuasan masyarakat. 
Hipotesis 5 menunjukan terdapat pengaruh positif dan signifikan variabel tangible (X5) terhadap kepuasan masyarakat. Pembuktian untuk hipotesis tersebut digunakan perbandingan t-hitung dengan t-tabel, dimana diperoleh nilai t-hitung lebih besar dari pada ttabel $(2,317>1,969)$. Hasil nilai $p$-value sebesar 0,021 < 0,05 (alpha 5\%), maka Ha diterima dan disimpulkan secara statistik pada tingkat kepercayaan 95\% terdapat pengaruh positif tangible (X5) terhadap kepuasan masyarakat.

\section{PENUTUP}

Dari hasil penelitian ini disimpulkan bahwa Tingkat Kepuasan Masyarakat Melalui Kualitas Pelayanan Informasi Pada Aplikasi KRL Access secara keseluruhan memperoleh hasil yang positif dan signifikan.

Elemen realibility merujuk kepada kemampuan perusahaan untuk memberikan pelayanan yang akurat sesuai dengan harapan konsumen tekait kecepatan, ketepatan waktu, tidak ada kesalahan, sikap simpatik sudah dilakukan dengan baik. Hal ini terlihat pada Fitur utama dari aplikasi KRL Access adalah menu Train Position dimana pengguna bisa mendapatkan informasi posisi real time dari KRL yang ingin digunakan. Posisi kereta dapat diketahui berdasarkan stasiun tempat pengguna akan naik KRL.

Elemen responsivness mengacu pada daya tanggap dalam memberikan pelayanan yang cepat atau responsif serta diiringi dengan cara penyampaian yang jelas dan mudah dimengerti PT KCJ senantiasa berusaha memberikan yang terbaik. Hal ini terlihat dengan melakukan penyempurnaan pada aplikasi sebelumnya yakni info KRL. Fitur yang membedakan pada KRL Access adalah kemampuan menyatukan informasi terkait posisi real time dan jadwal perjalanan KRL dengan informasi dari akun sosial media resmi PT KCJ. Penyampaian informasi maupun keluhan dari pelanggan KRL Access juga menyediakan menu khusus bagi pengguna untuk berinteraksi langsung dengan PT KCJ melalui surat elektronik.
Pada elemen assurance mengacu pada kemampuan perusahaan untuk menumbuhkan kepercayaan di mata pelanggan melalui keramahan dan pengetahuan staf dalam melayani PT KCJ berusaha memberikan layanan yanga terbaik dimana fitur baru yang ditawarkan pada aplikasi KRL Access semakin memudahkan pengguna jasa kereta commuter line, selain dapat mengetahui posisi kereta dan jadwal keberangkatan, para pengguna dapat langsung menyimak apa saja info terbaru yang disampaikan oleh KCJ melalui twitter, facebook, dan instagram cukup melalui satu platform saja.. Untuk elemen empathy yang mengacu pada perhatian perusahaan pada pelanggannya. Salah satu upayanya adalah melalui aplikasi KRL Access, pengguna juga bisa mendaftar untuk mendapatkan notifikasi langsung ke ponselnya saat ada informasi terkini seputar informasi penting terkait KRL. Informasi penting itu antara lain mencakup kebijakan baru dari PT KCJ, kondisi lintas, hingga info gangguan perjalanan.

Sedangkan untuk elemen tangible yang mengacu pada bukti konkret kemampuan suatu perusahaan untuk menampilkan yang terbaik bagi pelanggan. Aplikasi KRL Access menghadirkan fitur layanan informasi yang dapat dipahami dan dipelajari para penggunannya dalam waktu singkat, sehingga membantu informasi rute jadwal perjalanan KRL.

\section{UCAPAN TERIMA KASIH}

Ucapan terim kasih kami sampaikan kepada RISTEKDIKTI atas bantuan dana penelitian dan publikasi yang telah diberikan dalam bentuk PDP (Penelitian Dosen Pemula).

\section{REFERENSI}

Ghazali, I. (2016). Aplikasi analisis multivariate dengan program IBM SPSS 23. Semarang: Universitas Diponegoro.

Harjati, L., \& Venesia, Y. (2015). Pengaruh Kualitas Layanan Dan Persepsi Harga Terhadap Kepuasan Pelanggan Pada 
Maskapai Penerbangan Tiger Air Mandala. Widya Ekonomika, Vol. 1, Nomor 1, Oktober 2015, 64-74. https://www.neliti.com/publications/367 91/pengaruh-kualitas-layanan-danpersepsi-harga-terhadap-kepuasanpelanggan-pada-ma

Kotler, P., \& Amstrong, G. (2013). PrinsipPrinsip Pemasaran Edisi Ketujuh (7th ed.). Jakarta: Erlangga.

Lovelock, C., Wirtz, J., \& Mussry, J. (2013). Pemasaran Jasa: Manusia, Teknologi, Strategi: Perspektif Indonesia (Jilid 2). Erlangga.

Majid, S. A. (2015). Customer Service dalam Bisnis Jasa Transportasi. Jakarta:8 (8th ed.). Jakarta: PT Raja Grafindo Persada.

Nguyen, M., Ha, N. T., Anh, P. C., \& Matsui, Y. (2015). Service Quality and Customer Satisfaction: A Case Study of Hotel Industry in Service Quality and Customer Satisfaction : A Case Study of Hotel Industry in Vietnam, Asian Social Science, Vol, 11, No. 10 March 2015. https://doi.org/10.5539/ass.v11n10p73, http://www.ccsenet.org/journal/index.ph p/ass/article/view/47755

Oktariansyah, Damayanti, R., Usman, B., \& Eko, A. (2017). Analisis Kualitas Pelayanan Angkutan Umum (Transmusi) Melalui Kinerja Terhadap Kepuasan Masyarakat di Kota Palembang, Jurnal Manajemen dan Bisnis Sriwijaya, Vol 1, Nomor 15 Maret 2017, https://ejournal.unsri.ac.id/index.php/jm bs/article/view/5647

Panjaitan, J. E., \& Yuliati, A. L. (2016). Pengaruh Kualitas Pelayanan Terhadap Kepuasan Pelanggan Pada JNE Cabang Bandung. Derema Jurnal Manajemen, Vol. 11 No. 2, September 2016. https://ojs.uph.edu/index.php/DJM/articl e/view/197/130

Pertiwi, V., Aknuranda, I., \& Wijaya, S. Evaluasi Usability Pada Aplikasi KRL Access Dengan Menggunakan Metode Evaluasi Heuristik. Jurnal Pengembangan Teknologi Informasi dan
Ilmu Komputer, vol. 3, no. 3, p. 22352242, jan. 2019. ISSN 2548-964X. http://j-ptiik.ub.ac.id/index.php/jptiik/article/view/4626

.Sekaran, U. (2017). Metode Penelitian untuk Bisnis (e6) (6th ed.). Jakarta.

Sekilas PT Kereta Commuter Indonesia. (n.d.).

Sugiono. (2016). Metode Penelitian Kuantitatif, Kualitatif dan $R \quad \& \quad D$. Bandung: Alfabeta.

Tjiptono, F., \& Chandra, G. (2016). Service, Quality \& satisfaction. Yogyakarta: Andi.

\section{BIODATA PENULIS}

Ratnawaty Marginingsih, S.E., M.M, adalah alumni dari Universitas BSI Bandung dari Program Studi Magister Manajemen. Saat ini aktif sebagai Dosen di Universitas Bina Sarana Informatika, selain itu aktif sebagai anggota Unit Pengembangan Akademik prodi S1 Manajemen pada Fakultas Ekonomi dan Bisnis Universitas Bina Sarana Informatika, tercatat sebagai anggota Forum Akademisi Indonesia dan sebagai anggota Asosiasi Dosen Indonesia. Penelitian yang dilakukan terkait dalam bidang manajemen keuangan dan manajemen lainnya.

\section{Isnurrini Hidayat Susilowati, S.E., M.M..} lahir di Magelang Jawa Tengah menyelesaikan studi S1 di FE Universitas Sebelas Maret (UNS) Solo dan S2 Magister Manajemen di Institut Pertanian Bogor (IPB) Bogor. Pernah bekerja di PT.Bank Danamon Indonesia, Tbk Bone dan Pare-Pare Sulawesi Selatan sebagai Kepala Operasional dan Administrasi dan di PT. Bank Niaga, Tbk pada Divisi Marketing Komunikasi sebagai Koordinator Marketing Even. Saat ini aktif sebagai dosen pada Fakultas Ekonomi dan Bisnis Universitas Bina Sarana Informatika sejak tahun 2010 dan saat ini bergabung dalam Unit Pengembangan Akademik (UPA) Program studi Manajemen S1 Universitas Bina Sarana Informatika. 
Wiwik Widiyanti, S.P., M.M.

Dilahirkan di Purworejo, 11 Mei 1977.

Pada tahun 1995-2001 menempuh

pendidikan di jurusan Sosial Ekonomi

Pertanian Universitas Pembangunan

Nasional "Veteran" Yogyakarta dan pada tahun 2010-2012 melanjutkan pendidikan di jurusan Magister Manajemen Universitas BSI Bandung. Sejak tahun 2003 aktif sebagai pengajar di Program Studi Administrasi Bisnis Universitas Bina Sarana Informatika. 